\title{
Nobel corruption claims are 'totally without substance'
}

$\checkmark$ atoll appeared to have been affected by localized fracturing around each test site, subsidence and submarine landslides. However, the scientists suggested radiation leakage would not occur for 500 to 1,000 years.

In 1987, the French marine biologist Jacques Cousteau conducted a further study of Mururoa. His report, released in 1988, reinforced the Atkinson observations. Cousteau also concluded that nuclear tests on the atoll posed neither short nor midterm risks to the former volcano's geology.

Cousteau seems to have had a change of heart about the testing programme. He is now fervently antinuclear and has emerged as one of the French government's sternest critics, warning in an article in Le Monde last week of the dangers of undermining international efforts to reduce the dangers of eration.

The data from Cousteau's 1987 study, meanwhile, were re-evaluated by Greenpeace scientists in 1990. Norm Buske, chief scientist on board their ship Rainbow Warrior, sampled zooplankton in waters just outside the 12-mile exclusion zone from Mururoa. Buske claims to have found traces of caesium-134, a known product of nuclear fission which has a half-life of two years, although any link with the underground tests is difficult to establish.

A paper prepared by Australian scientists for a meeting of environment ministers from the South Pacific last month (see Nature 376, $625 ; 1995)$ concluded that "it is unlikely there will be major rupturing of the atoll as a result of the remaining eight tests, although there is insufficient evidence to be absolutely certain". But the scientists described as "more significant" the risks of long-term leakage of longer-lived radioisotopes into the lagoon and surrounding ocean.

Ehsan Masood nuclear non-prolif- Cousteau: tests carry

Munich. The Nobel prize committee has angrily rejected accusations that one of its members accepted payments from the Italian drug company Fidia as part of a campaign by the company to promote the nomination of the Italian neuroscientist Rita Levi-Montalcini for the 1986 Nobel prize for physiology or medicine.

The accusations, which come only a month before this year's awards are due and which have been described by the committee as "totally without substance" were made in a series of three articles published last week in Dagens Nyheter, Sweden's largest daily newspaper.

In particular, the newspaper claimed that Tomas Hökfelt, a professor of neuroscience at Stockholm's Karolinska Institute, had accepted favours from Fidia. These included payment for his wife to join him at a Fidiasponsored meeting in Madrid, and the acceptance of a Fidia prize worth US $\$ 2,000$ in 1986. The newspaper linked these with Hökfelt's support for Levi-Montalcini's nomination when he was a member of the Nobel prize committee.

Levi-Montalcini won the 1986 prize with the US researcher Stanley Cohen for her work on nerve growth factor in the 1950s. Her achievements opened up a broad new field of research on the mechanisms of nerve degeneration.

The Swedish newspaper says that it was not challenging the appropriateness of awarding the prize to Levi-Montalcini, nor making a personal attack on Hökfelt, but simply wanted to raise the question of whether the Nobel prize committee was potentially open to corruption.

The charges against Hökfelt are based on accusations - so far unproven - by Duilio Poggiolini, Italy's former head of drug regulatory affairs, that Fidia mounted a 14-billion lire (US\$8.7 million) campaign to

\section{Revised EC contracts improve property rights}

London. The European Commission in Brussels has introduced a new model for research contracts that strengthens the protection of intellectual property rights awarded to researchers working on projects partly funded by the European Union's Fourth Framework Programme.

The new contracts give research consortia the legal right to ownership of intellectual property resulting from work on a research project, and also reinforce the confidentiality requirements regarding unprotected, unpublished scientific results.

The new model contract, which is half the length of the current model introduced in 1988 , also clears up previous anomalies in this area, and provides a framework for the commercial exploitation of technology. It also required the submission of an implementation plan at or before the end of the contract - a move intended to improve the exploitation of research results.

The new format has been introduced on the initiative of Edith Cresson, who was appointed commissioner for science, research and development at the beginning of this year, and Martin Bangemann, commissioner for industry, telecommunications and information technology.

The new model contract is the outcome of extensive consultations with industry, academia and research organizations. assure the prize for Levi-Montalcini, as her work had implications for its own commercial products, the gangliosides, which in the 1980 s were candidate compounds for neurodegenerative disorders (see Nature 367, 672; 1994)

Poggiolini was arrested in 1993 on charges of corruption, and made the claim in court a few months later as part of his defence, arguing corruption was endemic. $\mathrm{He}$ is currently awaiting trial in Rome.

The newspaper's charges against Hökfelt arose from an examination of all his correspondence since 1982 - including thousands of letters - which the Karolinska Institute was obliged to release under Sweden's liberal freedom of information laws.

Sten Grillner, the chairman of the Nobel prize committee and professor of neuroscience at the Karolinska Institute, says he is appalled by the allegations against Hökfelt and the Nobel committee. "The newspaper has put together a story from unrelated facts that is completely without foundation."

Grillner claims that it would be impossible to corrupt the process of choosing Nobel prizewinners because of its complexity, and the fact that a large number of scientists is involved. "We also know that because the prize is so prestigious, it is always heavily scrutinized by the scientific public when it is announced," he says. "Up to now the prizes have been well-received."

He adds that he sees no reason why the selection process should be changed as a result of the accusations against the committee, adding that in his opinion all committee members are, by definition, of the highest integrity.

Hökfelt was the world's most cited neuroscientist in the 1980s, and Grillner says that both his position on the Nobel committee and invitations to scores of international meetings were due to his scientific eminence. It is entirely normal to accept expenses for attendance, he adds, and rejects the charge that this practice lays scientists open to corruption.

"If the Nobel prize committee were to prevent its members attending conferences with commercial sponsors, no-one would have attended any conference," says Grillner. Hökfelt has received at least ten scientific prizes, so the relatively small award he received from Fidia was not unusual, he says. "And if, as alleged, Fidia had mounted any campaign to influence the Nobel prize committee [in Levi-Montalcini's favour], we were certainly unaware of it," he says.

Hökfelt himself refuses to comment on the newspaper's charges, saying merely that the allegations against him "are totally unfounded".
Alison Abbott 